\title{
Rancang Bangun Alat Pendeteksi Warna Menggunakan Arduino Uno Berbasis IoT (Internet Of Things)
}

\author{
Sri Wulandari ${ }^{1}$, Budy Satria ${ }^{2}$ \\ ${ }^{1}$ AMIK Mitra Gama \\ e-mail: sriwulandariduri1@ gmail.com \\ ${ }^{2}$ AMIK Mitra Gama \\ e-mail: budysatriadeveloper@gmail.com
}

\begin{abstract}
Abstrak - Perkembangan teknologi yang demikian pesatnya menyebabkan rangkaian - rangkaian aplikasi elektronika menggantikan peran manusia sebagai ketelitian dan keakuratan dalam suatu pekerjaan. Berdasarkan hasil pengamatan dibidang industri, tidak sedikit yang masih menggunakan jasa tangan manusia untuk menyortir suatu benda, Pensortiran berdasarkan warna adalah salah satunya. Pendeteksi warna berbasis IoT ini merupakan simulasi suatu alat yang dirancang agar dapat membantu meringankan pekerjaan manusia dalam menyortir suatu benda. Teknik pendeteksi warna pada umumnya masih bersifat manual yang mengharuskan pengguna mengatur dari tempat alat itu berada. Oleh sebab itu, dibutuhkan sebuah alat yang mampu mendeteksi warna yang dapat diatur melalui aplikasi berbasis IoT (Internet of Things) menggunakan Sensor warna TCS3200 sebagai pendeteksi warna, Arduino Uno sebagai Data Processing dan aplikasi Microsoft Visual Basic .NET sebagai media interface-nya. Didukung dengan sistem HMI (Human Machine Interface) sebagai sistem yang mengatur proses jalannya suatu pekerjaan, dan Motor Servo sebagai actuator putar (motor) dalam mengarahkan objek yang sedang berjalan, pendeteksian warna akan lebih akurat dan efisien. Sehingga pengguna bisa mendapatkan atau mempermudah dalam mendeteksi warna sesuai jumlah yang diinginkan.
\end{abstract}

Kata Kunci: warna, arduino, internet of things

Abstract - The rapid development of technology causes a series of electronic applications to replace the role of humans as accuracy and accuracy in a job. Based on observations in the industrial sector, there are still few who use the services of human hands to sort an object. Sorting by color is one of them. This IoT-based color detector is a simulation of a tool designed to help ease human work in sorting an object. Generally, color detection techniques are still manual, requiring the user to adjust from where the tool is located. Therefore, we need a tool that can detect colors that can be adjusted through IoT-based applications (Internet of Things) using the TCS3200 color sensor as a color detector, Arduino Uno as Data Processing and Microsoft Visual Basic .NET applications as the media interface. Supported by the HMI (Human Machine Interface) system as a system that regulates the process of running a job, and a Servo Motor as a rotary actuator (motor) in directing a running object, color detection will be more accurate and efficient. So that users can get or make it easier to detect the color according to the desired amount.

Keywords: colour, arduino, internet of things

\section{PENDAHULUAN}

Perkembangan teknologi yang demikian pesatnya menyebabkan rangkaian-rangkaian aplikasi elektronika menggantikan peran manusia sebagai ketelitian dan keakuratan dalam suatu pekerjaan. Teknologi sebagai hasil penemuan ciptaan manusia untuk mempermudah pekerjaan manusia teknologi yang semakin maju dapat mempermudah manusia dalam memenuhi kebutuhan hidupnya di zaman modern seperti sekarang ini berbagai macam inovasi penemuan teknologi merambah dalam aspek kebutuhan manusia mulai dari transportasi, telekomunikasi, kedokteran, dan pertanian, sampai dunia industri yang semakin canggih dan berkembang (Permana, 2020). Teknologi yang canggih telah menggantikan peralatan-peralatan manual yang membutuhkan banyak tenaga manusia untuk dioperasikan, salah satunya yaitu penggunaan robot (Lesmana, Satria, \& Sari, 2020) Berdasarkan hasil pengamatan dibidang industri, tidak sedikit yang masih menggunakan jasa tangan manusia untuk menyortir suatu benda. Pengelompokan atau sortir dengan cara tersebut tentunya memiliki kekurangan dalam hal waktu dan tingkat produktivitas sutau kinerja.

Dengan perkembangan teknologi elektronika saat ini, telah banyak peralatan elektronika yang dirancang untuk membantu pekerjaan manusia. Pada bidang industri, peralatan-peralatan manual 
digantikan dengan peralatan elektronik yang dapat bekerja secara otomatis. Teknologi Informasi menggantikan peran manusia. Dalam hal ini, teknologi informasi melakukan otomasi terhadap suatu tugas atau proses (Kasma, 2019). Peralatanperalatan ini diantaranya digunakan untuk mempermudah pekerjaan, memperkecil biaya, meminimalisasi waktu, dan menghemat tenaga. Salah satu teknologi yang bisa bekerja otomatis yaitu sensor warna TCS3200 digunakan untuk berbagai kebutuhan, salah satu untuk mengetahui analisa beberapa objek warna yang didekatkan pada sensor untuk membedakan beberapa jenis objek warna pilihan, mengetahui cara kerja sensosr warna, supaya sensor warna tersebut bisa bekerja sesuai kebutuhan warna yang diperoleh (Zulkarnain, Ramadhan, \& Anwar, 2019). Tujuan dari penelitian adalah membuat Rancang Bangun Alat Pendeteksi Warna Menggunakan Arduino Uno Berbasis IoT (Internet of Things).

\section{IoT (Internet Of Things)}

IoT (Internet of Things) merupakan sebuah konsep yang memiliki tujuan untuk memperluas manfaat dari konektivitas internet yang tersambung secara terus menerus. Pada dasarnya, IOT mengacu pada benda yang dapat diidentifikasikan secara unik sebagai representasi virtual dalam struktur berbasis internet (Salamah, Taqwa, \& Wibowo, 2020).

\section{Sensor WARNA TCS3200}

Pada prinsipnya pembacaan warna pada TCS 3200 dilakukan secara bertahap yaitu membaca frekuensi warna dasar secara simultan dengan cara memfilter pada tiap tiap warna dasar. Untuk itu diperlukan sebuah pengaturan atau pemprograman untuk memfilter tiap-taip warna tersebut (Rahmad, 2019).

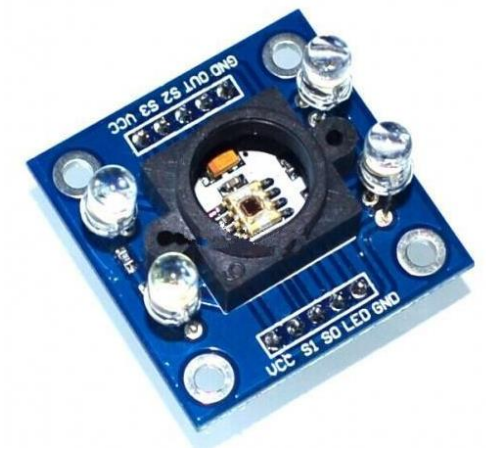

Gambar 1. Sensor Warna TCS3200

\section{Arduino Uno}

Uno Arduino adalah board berbasis mikrokontroler pada ATmega328. Board inimemiliki 14 digital input/output pin (dimana 6pin dapat digunakan sebagai output PWM), 6 input analog, $16 \mathrm{MHz}$ osilatorkristal, koneksi USB, jack listriktombol reset. Pin-pin ini berisi semua yang diperlukan untuk mendukung mikrokontroler, hanya terhubung kekomputer dengan kabel USB atau sumber tegangan biasa didapat dari adaptor AC-DC atau baterai untuk menggunakannya(Ahyuna \& Herlinda, 2020).

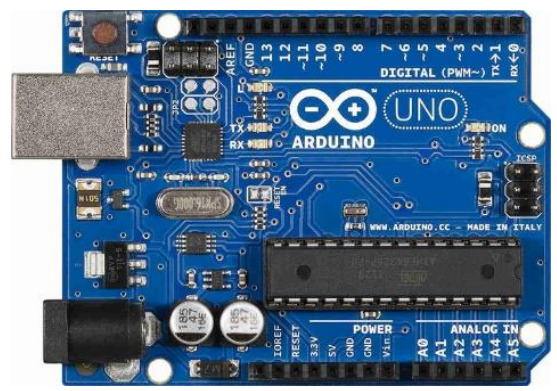

Gambar 2. Arduino Uno

\section{Rancang Bangun}

Rancang bangun merupakan kegiatan pembuatan sistem baru maupun pengembangan sistem yang sudah ada secara keseluruhan". Kesimpulannya adalah rancang bangun adalah penggambaran, perencanaan, dan pembuatan sketsa atau pengaturan dari beberapa elemen yang terpisah ke dalam suatu kesatuan yang utuh dan berfungsi (Handayani, Gunawan, \& Taufiq, 2020).

\section{Mikrokontroller}

Mikrokontroller adalah sebuah sistem komputer lengkap dalam satu chip. Mikrokontroller lebih dari sekedar sebuah mikroprosesor (Sabran \& Djawad, 2018).

\section{Motor Servo}

Motor servo adalah sebuah motor listrik dengan system umpan balik tertutup dimana posisi dar motor akan diinformasikan kembali ke rangkaian control yang ada di dalam motor servo (Mulyono, 2019).

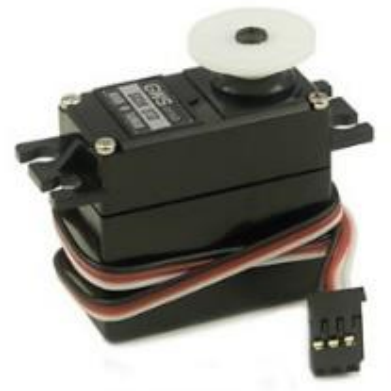

Gambar 3. Motor Servo 


\section{METODE PENELITIAN}

Metode penelitian yang digunakan adalah metode penelitian eksperimental, karena dapat menguji secara benar hipotesis yang menyangkut hubungan kasual melalui tahapan Design Science Research Method (DSRM) (Ramady, Yusuf, Hidayat, Mahardika, \& Lestari, 2020).

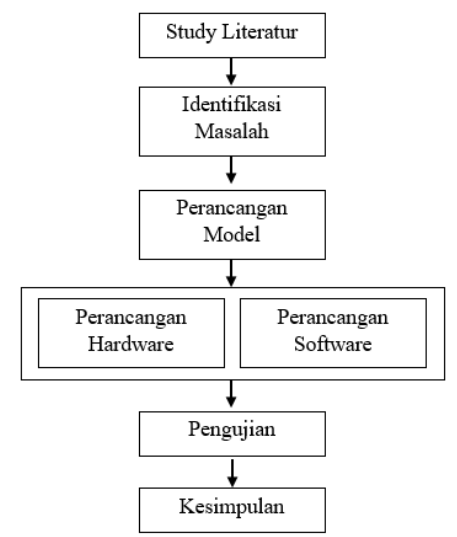

Gambar 4. Diagram Alur Penelitian

Beberapa tahapan pada penelitian eksperimental yang dilakukan adalah sebagai berikut :

1. Study Literatur, yaitu tahapan pertama dalam sebuah penelitian seperti pengumpulan informasi, daftar pustaka dan mengelola bahan penelitian.

2. Identifikasi Masalah, yaitu tahapan kedua dalam penelitian ini untuk mengidentifikasi permasalahan yang dihadapi.

3. Perancangan Model, yaitu tahapan ketiga dalam penelitian ini berupa kegiatan merancang hardware dan software sebagai implementasi dari solusi yang ditemukan.

4. Pengujian yaitu tahapan keempat yang dilakukan dalam penelitian ini berupa kegiatan testing model yang telah dibuat untuk mengukur fungsi dan kinerja sistem keseluruhan selanjutnya akan dilakukan evaluasi jika terhadap kesalahan saat pengujian.

5. Kesimpulan.

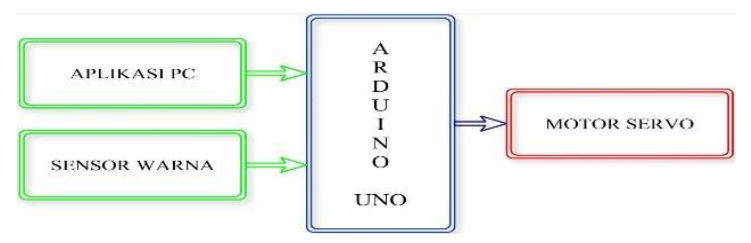

Gambar 5. Blok Diagram Sistem

Berdasarkan Blok Diagram pada Gambar 5 dapat terdapat beberapa komponen yang dapat dijelaskan sebagai berikut:
1. Aplikasi PC yang didesain untuk mengontrol benda berdasarkan warna. Aplikasi dapat berjalan jika sudah terhubung dengan alat. Jika tidak terhubung, aplikasi hanya dapat dibuka dan tidak dapat dijalankan.

2. Sensor pendeteksi warna merupakan bagian utama dalam pembuatan alat ini. Sensor digunakan untuk memberikan input yang nantinya akan dibaca oleh MikrokontroIler Arduino Uno.

3. Perancangan alat ini menggunakan dua motor servo, motor servo 1 berperan untuk mengarahkan objek ke sensor dan motor servo 2 digunakan untuk mengarahkan objek ketempat penampungan objek. Tempat penampungan warna diletakkan dibagian bawah sehingga objek dapat bergerak leluasa sesuai gravitasi setelah mendapat dorongan dari motor servo2. Sementara itu aplikasi akan terus menghitung dan mendeteksi objek sesuai warna jika alat masih ada objek.

Berikut akan dijelaskan secara rinci mengenai rancangan alat pendeteksi warna:

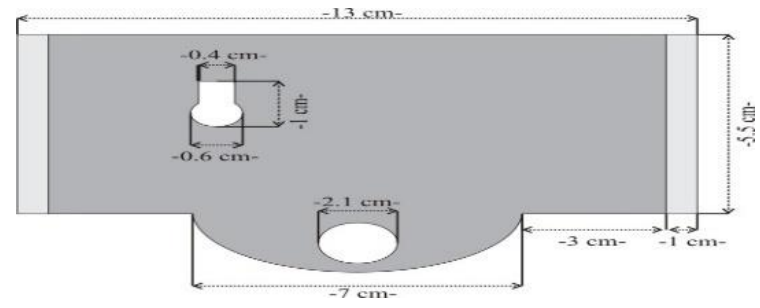

Gambar 6. Desain Box Atas

Gambar 6 diatas merupakan penyangga komponen seperti sensor warna, motor servo dan objek yang akan dideteksi warnanya.

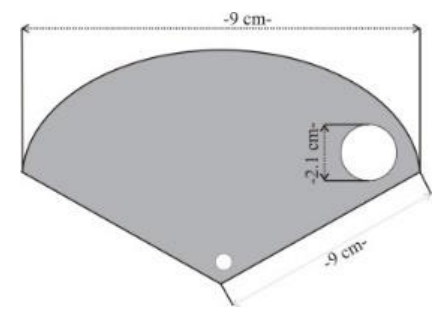

Gambar 7. Desain Pembawa Objek

Gambar 7 diatas merupakan rancangan pembawa objek ke sensor dan ke lubang pembuangan. Lubang yang tampak pada gambar diatas adalah lubang pengambil sekaligus pembawa benda. 


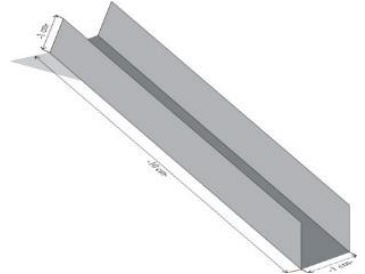

Gambar 8. Desain Pengarah Objek

Gambar 8 diatas merupakan rancangan Pengarah objek ke wadah penampungan sesuai warna akan didesain menyerupai talang air seperti tampak pada gambar diatas. Adapun tahapan dalam membuat rangkaian perangkas keras secara keseluruhan, yaitu

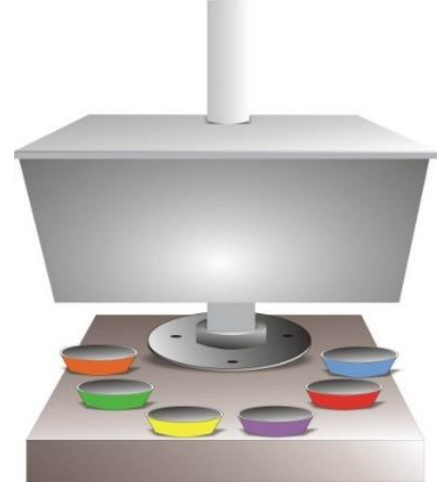

Gambar 9. Desain Alat Pendeteksi Warna

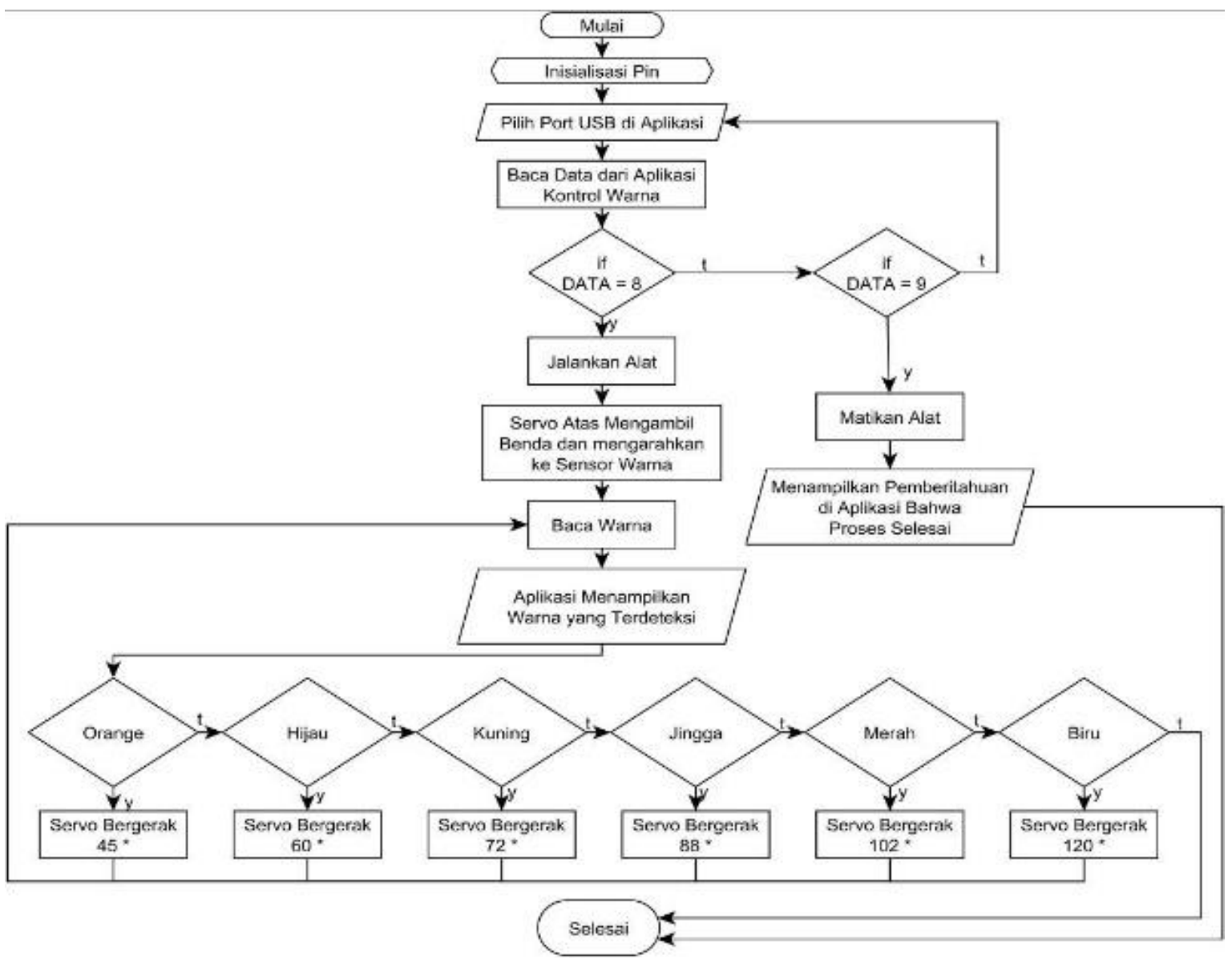

Gambar 10. Flowchart Kerja Sistem

Pada Gambar 10 diatas menunjukkan cara kerja sistem melalui diagram alir. Program akan melakukan koneksi ke aplikasi kontrol warna melalui port USB. Apabila ditemukan, alat akan bisa langsung dioperasikan. Jika data yang diterima dari aplikasi adalah 8, maka alat bisa langsung menjalankan proses selanjutnya. Jika data yang diterima adala 9, proses alat selesai. Hal ini akan ditampilkan pada aplikasi kontrol warna. Kemudian proses selanjutnya motor servo atas akan mengambil benda dan membawa benda kea rah sensor. Jika sensor sudah mendeteksi warna benda, maka arduino akan mengirimkan data ke aplikasi. Proses pembacaan warna adalah jika warna yang terdeteksi adalah warna merah, maka servo akan bergerak $45^{\circ}$. Jika tidak, maka sensor mendeteksi warna hijau dan servo bergerak $60^{\circ}$, dan seterusnya hingga warna tidak terdeteksi. Jika warna tidak terdeteksi, maka proses selesai. 


\section{Listing Program}

\#include $\langle$ Servo.h $>$

\#include "Wire.h"

int sensorPin $=A 5$;

int LedBiru $=2$; // Led warna biru digital pin 3

int LedHijau=3; // Led warna hijau digital pin 4

int LedMerah=4; // Led warna merah digital pin 5

int hasil,hasilb,hasilm, hasilh;

int $k=8$; // toleransi warna

Servo servo_atas;

Servo servo_bawah;

int warna $=0$;

int data, freq = false;

void setup() \{

Serial.begin(9600);

pinMode(LedBiru,OUTPUT);

pinMode(LedMerah,OUTPUT);

pinMode(LedHijau,OUTPUT);

digitalWrite(LedBiru,LOW);

digitalWrite(LedMerah,LOW),

\section{HASIL DAN PEMBAHASAN}

Pengujian dari alat yang telah dibuat ini dilakukan secara bertahap, pengujian dilakukan pada masingmasing blok rangkaian komponen elektronika yang terhubung dengan Arduino Uno, seperti Power Supply, sensor TCS3200, Motor Servo dan Relay. Adapun hasil rangkaian alat secara keseluruhan dapat dilihat pada Gambar 11 di bawah ini:

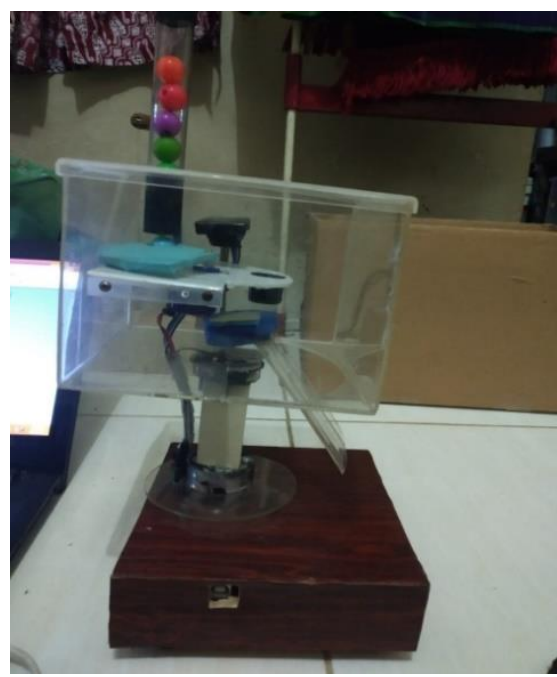

Gambar 11. Model Keseluruhan Desain Alat

\section{Langkah-Langkah Pengoperasian Alat}

Untuk melakukan pengoperasian secara umum dapat dilihat sebagai berikut :

1. Catu Daya (Power Supply) yang digunakan adalah menggunakan kabel data dari USB.

2. Setelah alat terhubung dengan arduino, maka alat pendeteksi warna sudah bisa di jalankan.

3. Selanjutnya, buka aplikasi control warna yang sudah diinstal. Caranya adalah klik start - control warna Wulan. Maka, akan tampil seperti pada Gambar 12 berikut ini.

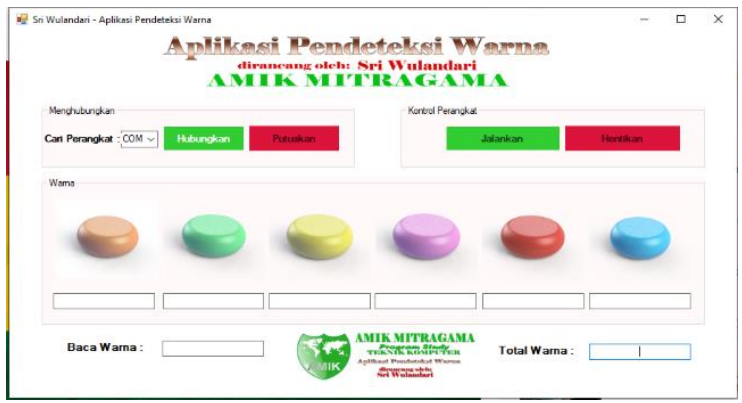

Gambar 12. Tampilan Aplikasi Pendeteksi Warna

4. Selanjutnya pilih port

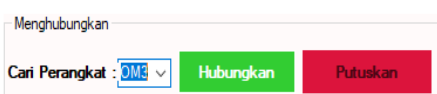

Gambar 13. Port yang digunakan

5. Selanjutnya, klik jalankan pada button aplikasi.

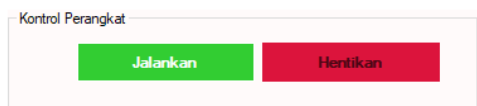

Gambar 14. Menjalankan Aplikasi

Setelah aplikasi dijalankan, maka alat akan aktif sesuai dengan intruksi program yang sudah dimasukkan kedalam arduino. Kemudian motor servo 1 akan mengambil bola warna seperti pada Gambar 15 berikut

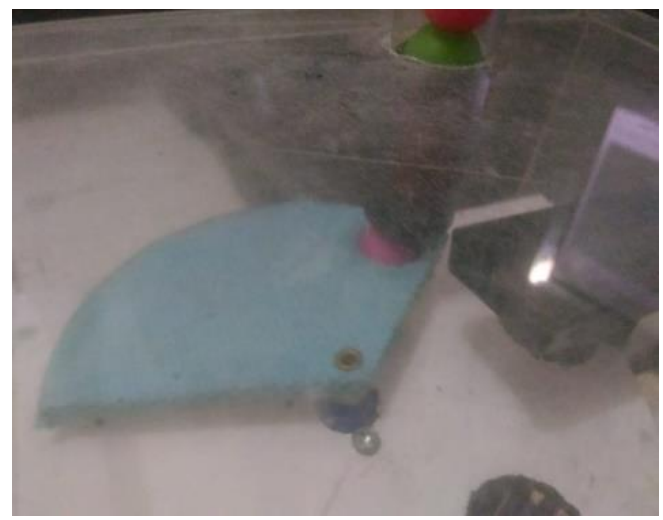

Gambar 15. Motor Servo Mengambil Bola Berwarna

Kemudian aplikasi akan menampilkan warna dan jumlah warna yang terdeteksi seperti Gambar 16 berikut. 


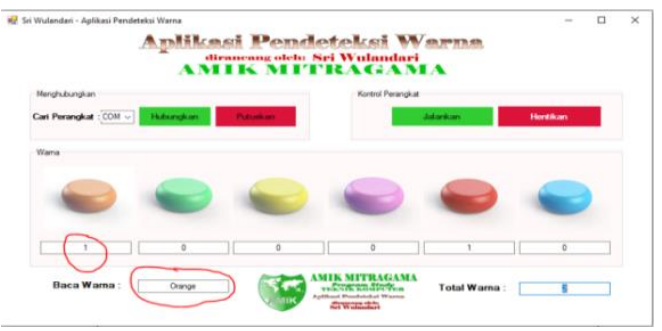

Gambar 16. Aplikasi Mendeteksi Warna

Ketika objek yang ingin dibaca dari aplikasi, maka motor servo I akan mengarahkan objek tersebut untuk dibaca oleh sensor TCS3200. Ketika sensor membaca warna yang akan dieskusi maka diberikan relay pada motor servo I untuk memberikan waktu kepada sensor TCS3200 untuk membaca warna objek yang akan diarahkan kepenampungan. Setelah sensor membaca warna objek maka motor servo II akan mengarahkan objek tersebut akan diarahkan ke penampungan yang sudah dirancang. Objek yang telah dibaca oleh alat akan terdata diaplikasi yang digunakan dan akan tampil jumlah objek yang akan diterdeteksi oleh alat diapliksi yang digunakan

\section{Pengujian Sistem}

Untuk pengujian modulMikrokontroller Arduino Uno berkerja dengan baik akan dilakukan pengujian pada jalur-jalur port yang dimiliki oleh Mikrokontroller Arduino Uno. Untuk pengujian modul dilakukan pengisian program terlebih dahulu menggunakan Arduino IDE (Integrated Development Environment). Dengan meng-compile program ke mikrokontroller ini dapat mengetahui adanya error atau tidak. Untuk menjalankan program, caranya dengan menghubungkan langsung antara komputer dengan modul mikrokontroller Arduino Uno. kemudian lihat pada Arduino IDE (Integrated Development Environment) apakah program berhasil terupload. Bila berhasil, berarti modul Arduino Uno dapat digunakan.

Berikut adalah langkah pengujian mengenai komunikasi antara papan Arduino dan laptop: Menghubungkan mikrokontroller dengan komputer/laptop dengan menggunakan USB Cable Max dan menulis serta meng-upload sketch dibawah menggunakan software Arduino IDE (Integrated Development Environment),

void setup ())

Serial.begin(9600); \}

void loop()i

while (Serial.available() $!=0$ )

$\{$ char data $=$ Serial.read () ;

Serial.print(data);

$\operatorname{delay}(20) ;\}\}$

Skecth di atas digunakan untuk menghubungkan mikrokontroller dengan komputer sebagai bentuk pengujian terhadap sistem yang dibuat.

\section{Pengujian Motor Servo}

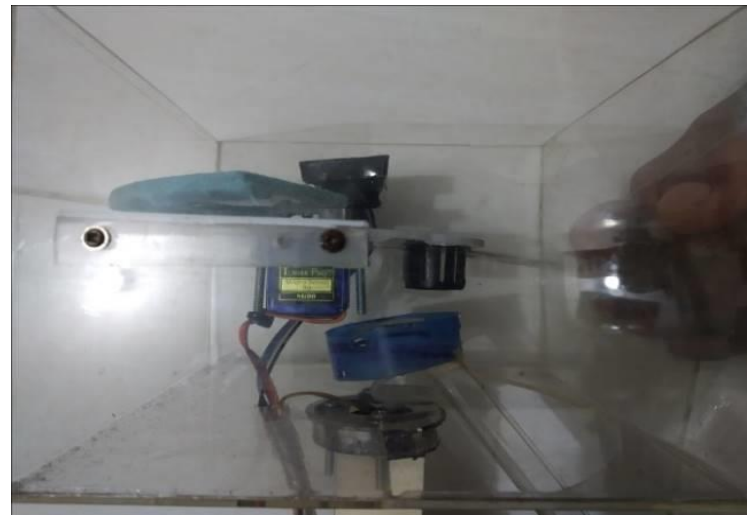

Gambar 17. Bentuk Fisik Motor Servo

Motor servo yang pertama berfungsi untuk mengambil bola warna kemudian mengarahkan ke sensor. Pengujian motor servo dilakukan untuk megetahui keakuratan bergerak servo yang dilakukan.

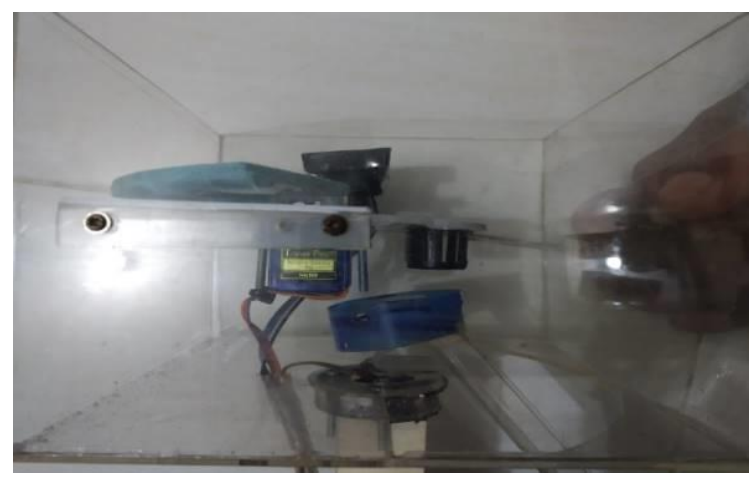

Gambar 18. Keadaan Motor Servo I

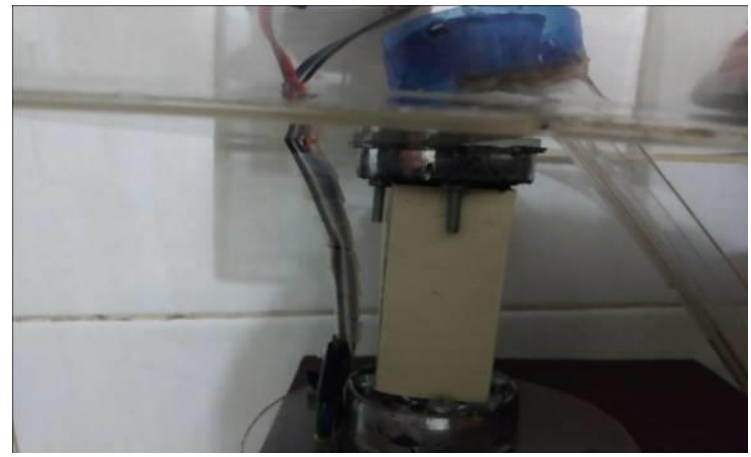

Gambar 19. Keadaan Motor Servo II

\section{Pengujian Sensor Warna}

Berikut adalah tabel hasil pengujian dari data warna yang telah diuji :

Tabel 1. Pengujian Sensor Warna TCS3200

\begin{tabular}{|c|c|c|c|}
\hline \multirow{2}{*}{$\begin{array}{c}\text { Objek } \\
\text { Warna }\end{array}$} & \multicolumn{3}{|c|}{ Data Saat Bola Warna terdeteksi } \\
\cline { 2 - 4 } & $\mathbf{R}$ & $\mathbf{G}$ & B \\
\hline Jingga & 235 & 102 & 15 \\
\hline
\end{tabular}




\begin{tabular}{|c|c|c|c|}
\hline Hijau & 4 & 230 & 11 \\
\hline Kuning & 215 & 238 & 5 \\
\hline Ungu & 170 & 7 & 235 \\
\hline Merah & 229 & 10 & 15 \\
\hline Biru & 6 & 9 & 241 \\
\hline
\end{tabular}

Berdasarkan Tabel 1 di atas dapat dijelaskan pengujian warna dilakukan pada 6 warna yang berbeda sebagai objek untuk dideteksi oleh alat ini yaitu Orange, Hijau, Kuning, Merah, Ungu dan Biru. Terlihat jelas bahwa terjadi perubahan nilai RGB.

\section{PengukuranHasil Persentase Warna RGB}

Pengukuran dilakukan dengan metode langsung dengan membandingkan nilaialat yang sudah dibuat. Pengukuran dilakukan terhadap 6 warna berbeda. Persentase diatas dihitung menggunakan jumlah nilai keseluruhan warna tersebut yaitu 255 sesuai dengan standar warna yang telah ditentukan.

Tabel 2. Pengukuran Persentase Warna RGB (\%)

\begin{tabular}{|c|c|c|c|}
\hline \multirow{2}{*}{$\begin{array}{c}\text { Objek } \\
\text { Warna }\end{array}$} & \multicolumn{3}{|c|}{ Persentase Warna RGB (\%) } \\
\cline { 2 - 4 } & $\mathbf{R}$ & $\mathbf{G}$ & $\mathbf{B}$ \\
\hline Jingga & 92,15 & 40 & 5,88 \\
\hline Hijau & 1,56 & 90,19 & 4,31 \\
\hline Kuning & 84,31 & 93,33 & 1,96 \\
\hline Ungu & 66,67 & 2,74 & 92,15 \\
\hline Merah & 89,80 & 3,92 & 5,88 \\
\hline Biru & 2,35 & 3,52 & 94,50 \\
\hline
\end{tabular}

Dari Tabel 2 di atas, maka hasil persentase warna RGB dapat dihitung dengan rumus berikut :

\section{Persentase (\%) = Jumlah Bagian/Jumlah} Keseluruhan $\times 100 \%$

\section{Jingga}

$\% \mathrm{R}=(235: 255) \times 100 \%$

$\% \mathrm{G}=(102: 255) \times 100 \%$

$=92,15 \%$

$=40 \%$

$\% \mathrm{~B}=(15: 255) \times 100 \%=5,88 \%$

\section{Hijau}

$\% \mathrm{R}=(4: 255) \times 100 \%$

$\% \mathrm{G}=(230: 255) \times 100 \%$

$=1,56 \%$

$=90,19 \%$

$=4,31 \%$

\section{Kuning}

$\% \mathrm{R}=(215: 255) \times 100 \%$

$\% \mathrm{G}=(238: 255) \times 100 \%$

$\% \mathrm{~B}=(5: 255) \times 100 \%$

$=84,31 \%$

$=93,33 \%$

$=1,96 \%$

\section{Ungu}

$\% \mathrm{R}=(170: 255) \times 100 \%$

$\% \mathrm{G}=(7: 255) \times 100 \%$

$=66,67 \%$

$=2,74 \%$

$\% \mathrm{~B}=(235: 255) \times 100 \%$

$=92,15 \%$

\section{Merah}

$\% \mathrm{R}=(229: 255) \times 100 \%$

$\% \mathrm{G}=(10: 255) \times 100 \%$

$=89,80 \%$

$=3,92 \%$

$\% \mathrm{~B}=(15: 255) \times 100 \%$
6. Biru

$\begin{array}{ll}\% \mathrm{R}=(6: 255) \times 100 \% & =2,35 \% \\ \% \mathrm{G}=(9: 255) \times 100 \% & =3,52 \% \\ \% \mathrm{~B}=(241: 255) \times 100 \% & =94,50 \%\end{array}$

\section{KESIMPULAN}

Pada penelitian ini, Mikrokontroller Arduino dapat digunakan untuk mengakses sensor warna TCS3200 sebagai pendeteksi warna. Nilai warna RGB dapat berubah-ubah pada hasil deteksi sensor tergantung pada tingkat cahaya dan ruangan tempat mendeteksi warna. Terdapat 6 warna yang digunakan sebagai objek untuk menguji sesnsor warna TCS3200. Dengan memanfaatkan perancangan pembuatan alat pendeteksi warna ini secara otomatis dapat menggantikan peran manusia dalam hal penyortiran suatu benda agar meringankan pekerjaan manusia. Mengontrol dan memonitor jumlah warna dengan menggunakan aplikasi sehingga dapat memonitor jumlah warna yang telah berhasil direkam oleh sensor TCS3200.

\section{REFERENSI}

Ahyuna, \& Herlinda. (2020). Pembuatan Alat Pemisah Buah Kopi Otomatis Berdasarkan Warna Menggunakan Sensor Warna TCS230 Berbasis Mikrokontroler. Jurnal Ilmiah MATRIK, 22(2), 139-146.

Handayani, T., Gunawan, I., \& Taufiq, R. (2020). Rancang Bangun Sistem Informasi Pemesanan Menu Makanan Berbasis Web (Studi Kasus: Restoran Bukit Randu Bandara). Jurnal SITECH: Sistem Informasi Dan Teknologi, 3(1), 21-28. https://doi.org/10.24176/sitech.v3i1.4837

Kasma, U. (2019). Peranan Teknologi Informasi Dalam Mendukung Proses Belajar Siswa. Seminar Nasional Hasil Pengabdian Kepada Masyarakat 2019, 144-148.

Lesmana, D., Satria, B., \& Sari, Y. R. (2020). ROBOT ARM (ADVANCED RISCMACHINE) PEMINDAH BARANG OTOMATIS BERDASARKANWARNA MENGGUNAKAN ARDUINO UNO R3. Jurnal Teknologi Dan Open Source, 3(2), 176-186.

Mulyono, M. A. (2019). Simulasi Alat Penjaring Ikan Otomatis Dengan Penggerak Motor Servo Continuous , Sensor Jarak Hc-SR04 dan Tombol Menggunakan Arduino Mega. Jurnal Ilmiah Ekonomi Dan Bisnis, 12(1), 39-47.

Permana, I. (2020). PROTOTIPE RANCANG BANGUN PINTU BENDUNGAN OTOMATIS UNTUK IRIGASI PERTANIAN BERBASIS MIKROKONTROLER 
ARDUINO ATMEGA328. JURNAL FASILKOM, 10(2), 97-102.

Rahmad, I. F. (2019). Pendeteksi Kesegaran Buah Menggunakan Sensor Warna dan Kelembaban. Jurnal Riset Komputer (JURIKOM), 6(5), 550-558.

Ramady, G. D., Yusuf, H., Hidayat, R., Mahardika, A. G., \& Lestari, N. S. (2020). Rancang Bangun Model Simulasi Sistem Pendeteksi Dan Pembuangan Asap Rokok Otomatis Berbasis Arduino. Jurnal Teknik Komputer AMIK BSI, VI(2), 212-218. https://doi.org/10.31294/jtk.v4i2

Sabran, \& Djawad, Y. A. (2018). Perancangan Modul Pembelajaran Berbasis Projek Pada Matakuliah Dasar Mikrokontroler. Jurnal MEKOM (Media Komunikasi Pendidikan Kejuruan), 5(1), 23-31.

Salamah, I., Taqwa, A., \& Wibowo, A. T. (2020). Rancang Bangun Sistem Keamanan Sepeda Motor Berbasis SMS Gateway. JURNAL FASILKOM, 10(2), 103-112.

Zulkarnain, I., Ramadhan, M., \& Anwar, B. (2019). Implementasi Alat Pendeteksi Warna Benda
Menggunakan Fuzzy Logic dengan Sensor TCS3200 Berbasis Arduino. Jurnal Teknologi Sistem Informasi Dan Sistem Komputer TGD, 2(2), 106-117.

\section{PROFIL PENULIS}

Budy Satria, S.Kom., M.Kom. Tahun 2014 lulus dari Program Strata 1 (S1) Program Studi Sistem Informasi di Universitas AMIKOM Yogyakarta. Tahun 2018 lulus dari Program Strata 2 (S2) Program Studi Teknik Informatika di Universitas Putra Indonesia "YPTK" Padang. Saat ini menjadi Dosen Tetap Program Studi Teknik Komputer di AMIK Mitra Gama.

Sri Wulandari, A.Md. Tahun 2019 lulus dari Program Diploma III (D3) Program Studi Teknik Komputer di AMIK Mitra Gama. Saat ini menjadi karyawan di Kelurahan Air Jamban, Duri, Riau. 